\section{5. 前拎角測定に関する一考察}

鳥取県立整肢学園

（園長 池田 正二） 飯田 武男

大腿骨頸部前拾角の測定は股関節疾患等の骖断上しば しば行なわれる。しれについて從来の方法と当学園にて 簡単に撮影する方法とを比較検討を加えた。

正面像の撮影では誛台の端に下腿を下垂した仰臥位で 両膝関節を出来るだけ密着させ両足関節を出来るだけ開 かせて撮影する．しの位置では大腿骨は内旋し大転子小 転子間の転子間線の前後が重なる様になり前捻角の影響 のなし頸体角が計測される．乙の頸体角の補角を前捻角 の撮影に用いるる。

前捻角の撮影は葠台上に仰卧させ両脚を腰掛に掛けた 様に大腿部を身体と直角に保ち下腿を身体と平行になる 様に直角に屈曲させる. 予为測定した頸体角の補角だけ 身体の中心線より大腿部を外転させる．乙の位置で大腿 骨頸部の中心線の高さはフィルムと平行になり頸体角の 影響はなくなる。下腿は大腿骨の腿側顆と腓側顆の下端 が下腿と直角になる様に内外転して調整して撮影する.

大腿骨下部の脛側顆腓側顆の下端を結んだ線の延長と 大腿骨頸部中心線とのなす角が前捻角でありとの角は頸 体角の影響はなくなる．Dunlap-Ryder 氏法及じ甲斐氏 法と本法との比較は甲斐氏法では本法より小さな值であ

り Dunlap-Ryder 氏法は本法より大きな值であった。

標本骨についての実測值と以上三法の比較に於ても本 法が最む実測值に近くその誤差は土 2 度に過ぎないが他 の二法は更に大きな誤差を示した。

また当学園入園中の肢体不自由児中股関節に異常のな い者13例に於ても三法の比較は甲斐氏法は本法より小さ く, Dunlap-Ryder 氏法は大きな值を示し標本骨と同様 であった。

以上前揄角の測定は股関節疾患の診断治療上重要であ るに拘わらず生体の正確な測定は困難であるが本法は一 度に両方の撮影が出来ない不便はあるが, 従来の方法に 比べ簡単で正確な方法と考え臨床上大いに利用すべき方 法と考える。

\section{追加}

前揄角の測定には立位式回転横断装置を使用する方法 が非常に正確で且つ広範囲に応用出来るので追加報告し ます。

方 法

Indicater を垂直に被写体の前方に立てて，大転子を 合む骨頭の横断像及び大腿骨顆部の横断像を撮影する.
この二枚の写真の Indicater を合わせて大腿骨顆後接 線及び大腿骨骨頭，大転子の中心を通る直線を求める (スライド)この一直線の交わる角が前捻角となります.

本法は特に股関節の立体形態の把握に必要な撮影法で あると考えられます。

（青森 上田）

\section{兵問}

前捻角測定の場合股関節のコウシュクが有る時には頸 体角の補角がとれないと思うが.

(山口 篠崎) 答

(1) コウシュクのあるものは通常内旋位になっている あのが多い.

(2)転子間線が一線になる様に再撮影する.

\section{6. 妊娠末期における立位撮影法の検討}

\begin{tabular}{|c|c|c|}
\hline 葛飾赤十字産院 & 院長 & 新正至 \\
\hline 理学診療部 & & 茶金９１－ \\
\hline
\end{tabular}

\section{目 的}

妊娠 8 力月〜 10 力月までの胎児 $\mathrm{X}$ 線撮影は従来行なわ れています。撮影法では妊婦が非常に苦痛と不安を訴え， それがために種々の因子を生じて，普通でさえむつかし い条件が一層診断的価值を低下させております。合回は 從来行なっておりました，撮影方法と比較対象的に腹部 (胎児)立位撮影法を行ない比較検討した所従来の背腹撮 影法と比較してその診断的価値も余り差はなく，且つ妊 婦の苦痛と不安む少ない好成績を得たので撮影条件等を 比較して発表致します。.

方 法

先ず体位でありますがりーダー氏撮影台に大陸用フィ ルムを固定して妊婦にはその前面に胸部撮影と同様直立 不動の姿勢を取らせます。

その後方 $100 \mathrm{~cm}$ の距離で $\mathrm{X}$ 線管を国定 $\mathrm{X}$ 線照射して 目的のX線写真を得る方法であります。

徉来腹位撮影法, 背腹撮影法, 側位撮影法の三方法が ありますが，それぞれの優れた特長がありまず。またそ の反面に少なからず久点を見逃す訳には参りません，腹 位撮影では腹部の圧迫による苦痛と不安と言う大きな久 点があり, 日常の胎児撮影では殆んど全部の妊婦から苦 痛と不安を訴えられました。また背位撮影では胎児とフ ィルムが離れ過ざるためにX線学上一番重要である鮮鋭 度が悪くなる事と多胎弤娠の場合等に同一フィルム上に 全胎児を撮影する事が出来なくなりなります。側位撮影 では脂肪過多の妊婦と尖腹の妊娠を撮影する方法ですが これは側面像ですから診断上大変不都合な場合も生じて 来ます．従来の何れの撮影法でむ妊婦が大変苦痛之不安 を訴えましたが腹部(胎児)立位撮影法を行なってみまし 
て，その不安と苦痛が取除かれました，妊娠 8 カ月〜10 カ月までの妊婦に立位撮影を応用して検討した所月数が 増すに従って従来の腹位撮影法の方がX線写真上では鮮 鋭度が大となります，立位撮影でも鮮鋭度の良い写真を 得るためには管電圧と時間を増す事が必要となりますが， 乙れは放射線被懪線量が妊婦に対しまた胎児住対して腹 位撮影にくらべて大きくなるため出来るだけ線量の少な い方法で診断的優位なX線写真を得るのが妊婦のためま た胎肾のためでああると考えます。てての対策として月数 の增すに従って妊婦に腹帯のまま立位撮影を行えば線量 を著しく増加する事なく良い写真を得られますので撮影 条件等を図表で現わしてみました。

\section{使用装置及び条件}

X線装㯰 東芝 KXO-15 型高電压装置 G-3型，全波整流

$\begin{array}{ll}\text { X線管球 } \quad \text { DRX 90型 } & 2 \times 2 \quad 1 \times 1 \\ \text { 焦点フィルム間距離 } & 100 \mathrm{~cm} \\ \text { 管電王 } & 75 \mathrm{kVp} \\ \text { 管電流 } & 100 \mathrm{~mA} \\ \text { 時 間 } & 1.0 \sim 1.5 \text { 秒 } \\ \text { 腹 檿 } & 28 \mathrm{~cm} \sim 35 \mathrm{~cm}\end{array}$

立位背腹撮影条件表

\begin{tabular}{|c|c|c|c|c|c|c|c|}
\hline & 月数 & $\begin{array}{l}\text { 管電 } \\
\mathrm{kV} \text { p }\end{array}$ & $\begin{array}{l}\text { 管電 } \\
\mathrm{mA}\end{array}$ & $\begin{array}{c}\text { 距離 } \\
\mathrm{cm}\end{array}$ & $\begin{array}{c}\text { 時 } \\
\text { 間 } \\
\text { 秒 }\end{array}$ & $\begin{array}{l}\text { 外測 } \\
\mathrm{cm}\end{array}$ & $\begin{array}{c}\text { 子宮底 } \\
\mathrm{cm}\end{array}$ \\
\hline 立位 & 8ヶ月 & 60 & 100 & 100 & 1.0 & 28 & $(23) \sim 27$ \\
\hline 背腹 & 8 ケ月 & 64 & " & " & 1.0 & 28 & " \\
\hline 立位 & 9 ケ月 & 66 & " & " & 1.2 & 30 & $(27) \sim 31$ \\
\hline 背腹 & 9 ケ月 & 67 & " & " & 1.3 & 30 & " \\
\hline 立位. & 10ケ月 & 70 & " & " & \multicolumn{3}{|c|}{$|1.3 \sim 1.5| 34 \sim 35(30) \sim 35$} \\
\hline 背腹 & 10ケ月 & 75 & " & " & $1.3 \sim 1.5$ & $34 \sim 35$ & " \\
\hline
\end{tabular}

（）印は初期の場合定示す。 月数 $\times 3=$

(例) 9 ケ月 $\times 3=27 \mathrm{~cm}$

従来の撮影法の欠点

脊腹撮影法の欠点
(A) 妊婦の压迫に上る苦痛
（B）胎览の胎位勢を変えるととがある. 立位撮影法の利点
（A）日常妊娠よりの訴えの大きかった苦痛と不安が 除去された。
(B) 胎位胎勢に余り変化がない。

結 論

従来腹部(胎児)のX線撮影は原則として腹位撮影か背
腹撮影とされておりますが立位撮影法を行なう事によっ て弤婦の苦痛と不安がなくなり診断上にも余り変りなく 放射線障害予防にあよりと思われすす。皆様の御指導を 御願いします。

\section{7. 眼動脈主幹造影像のドイツ水平面となす角度測定} 九州厚生年金病院放射線科

$$
\begin{aligned}
& \text { 増 野 豊・岡部 健吾・田中 高生 } \\
& \text { 成田 寅彦・吉武 清秀高堀尾 重治 } \\
& \text { 松尾 春生 }
\end{aligned}
$$

視神経管撮影に当たり, 生体の視神経管とドイツ水平 面とのなす角度を知るととは困難である。促来頭蓋標本 による計測值が発表され，乙れを資料として視神経管撮 影を行なって来たが, 吾々は眼動脈主幹が頸動脈から分 岐して, 視神経直下を走って, 視神経管内で交差して上 に向きを変えるととに着目し，乙の主幹造影像とドイッ 水平面とのなす角度を計測して間接的に生体に打的視 神経管のドイツ水平面とのなす角度を求める目的を以っ て, 当院における脳血管造影側面像よりとれを計測推計 した.

\section{結 論}

眼動脈主幹が项動脈から分肢して，視神経直下を走り， 視神経管内で交差し，上に向きを変えるととに着目し

1） 49 例の脳血管側方径 $X$ 線写真より, 眼動脈主幹像 軸とドイツ水平面との傾斜角度を計測推計し, 平均值 19 度を得た。これを生体に㧍汀る視神経管とドイツ水平面 とのなす角度に代えた。

2）眼動脈主幹像軸とドイツ水平面との交点より腿窝 下縁までの距離を計測推計し， $1.98 \mathrm{~cm}$ を得た。

3）上記の推計値より, 眼動脈主幹像軸の延長線办眼窩 口を通過する点を計測し眼简下線縁より $0.68 \mathrm{~cm}$ 上の点 を通るととを知った。乙れは視神経管撮影に当たり，中 心X線の眼简口通過点を指す。

以上の值を臨床に応用し好結果を得ているので報告し， 諸賢の御批判を仰ぐ。

\section{8. 軟 X 線撮影法の検討（第 1 報）}

東芝玉川工場. 渡辺 広行・幾瀬 純一 三重大学医学部付属塩浜病院中央放射線部 中村 実・O川本 澄夫・古田 儀之 軟 $\mathrm{X}$ 線撮影法の基礎的並びに技術的諸問題, 即ち人体 軟部組織の軟 $\mathrm{X}$ 線撮影に用いるX $\mathrm{X}$ 線管の選択, 散乱線己 その除去法, 特に乳房撮影の新しい埋没法に用いる物質 について考察を加えると共にこれらの結果に基づきノ一 ンスクリーンフィルムによる実写を行なった。 